\title{
Catalytic Friedel-Crafts Reactions of Highly Electronically Deactivated Benzylic Alcohols
}

\author{
Vuk D. Vuković, Edward Richmond, Eléna Wolf, Joseph Moran*
}

\begin{abstract}
Highly electronically deactivated benzylic alcohols, including those with a $\mathrm{CF}_{3}$ group adjacent to the $\mathrm{OH}$-bearing carbon, undergo dehydrative Friedel-Crafts reactions upon exposure to catalytic Brønsted acid in HFIP solvent. Titration and kinetic experiments support the involvement of higher order solvent/acid clusters in catalysis.
\end{abstract}

The Friedel-Crafts reaction is a transformation of central importance for the synthesis of industrially relevant arenes and heteroarenes. ${ }^{1,2}$ The classical version requires stoichiometric quantities of Lewis acid and uses alkyl halides as starting materials, which are often generated in a separate step from alcohol precursors. Variants developed recently by Bode and Stephen have expanded the scope of the Friedel-Crafts reaction to include electronically deactivated benzylic electrophiles through the use of benzylic $\mathrm{N}$-methylhydroxamic acids and fluorides, respectively (Figure $1, a){ }^{3}$ However, like the classical version, these reactions require additional steps for substrate pre-activation and use stoichiometric activating agents. The need to improve the step- and atom-economy of the FriedelCrafts reaction prompted the ACS Green Chemistry Pharmaceutical Roundtable to designate the development of catalytic versions starting directly from alcohols that produce water as the only stoichiometric by-product as a top priority for green chemistry. ${ }^{4}$ Accordingly, the past years have witnessed numerous reports of Lewis or Brønsted acid catalyzed FriedelCrafts reactions of electronically activated benzylic alcohols, ${ }^{5,6,7}$ but the inability to use electronically deactivated alcohols remains a striking limitation. For example, the ferrocenium hexafluoroantimonate boronic acid catalyst developed by Hall and McCubbin, arguably the most active catalytic system described to date, reaches its limits at primary benzylic alcohols bearing modestly deactivating substituents and restricts access to highly fluorinated molecules of potential interest to the pharmaceutical and agrochemical industries (Figure 1, b). ${ }^{61}$ Recently, we observed that hydrogen bonding interactions between Brønsted acid catalysts and co-catalysts or solvents can have profound accelerating effects and even change the kinetic concentration dependence in catalytic substitution reactions of alcohols. ${ }^{8}$ Herein we report that interactions between Brønsted acid catalysts and solvents of low nucleophilicity known to form $\mathrm{H}$-bond clusters, such as hexafluoroisopropanol (HFIP), ${ }^{9,10,11}$ can be exploited to surpass current limitations of the catalytic dehydrative Friedel-Crafts reaction by enabling reactivity of highly electronically deactivated benzylic alcohols, including those bearing a geminal $\mathrm{CF}_{3}$ group. This new method grants access to deactivated, often highly

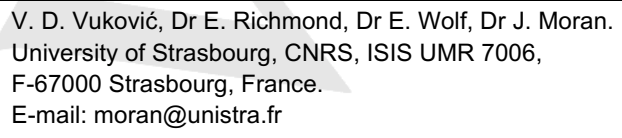

Supporting information for this article is given via a link at the end of the document. fluorinated, diarylmethanes and diaryltrifluoroethanes from the corresponding alcohol in a single catalytic step (Figure 1, c). Mechanistic experiments support the involvement of higher order solvent/acid clusters and point to an $\mathrm{S}_{N} 1$-type mechanism.

a) Preactivation (Bode, Stephan, ref. 3a-b)
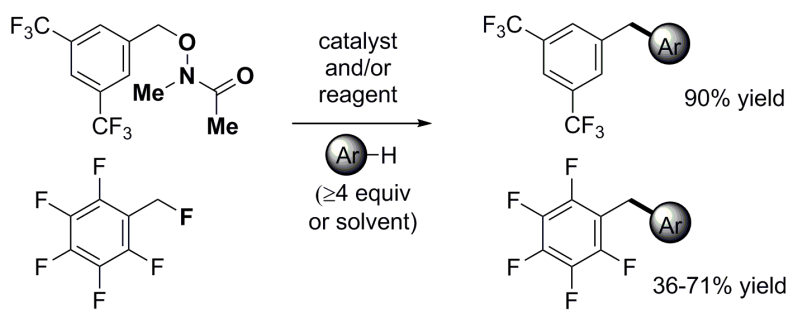

b) Direct (Hall \& McCubbin, ref. 6i; many others, refs. 5-7)

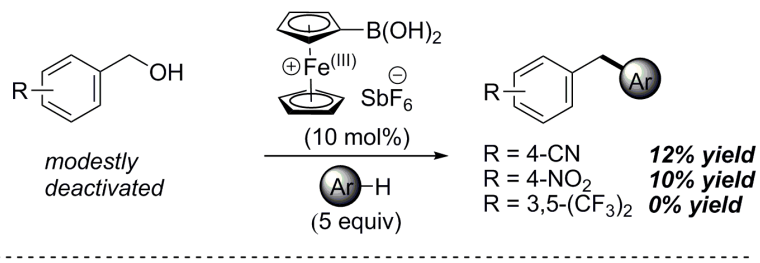

c) This work
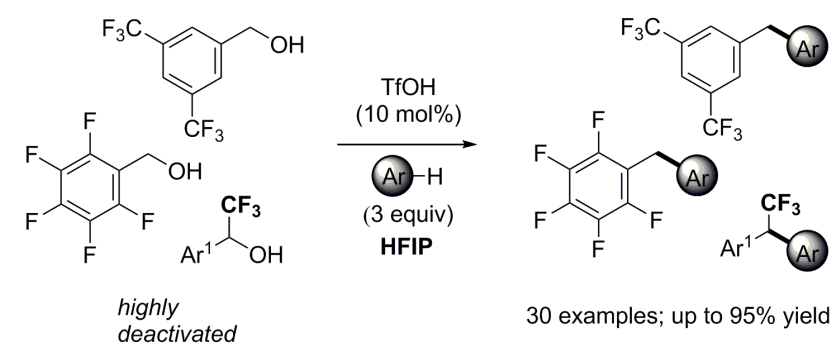

30 examples; up to $95 \%$ yield

Figure 1. Friedel-Crafts reactions of highly electronically deactivated benzylic electrophiles.

Initial experiments targeted Friedel-Crafts reactivity of $m$ xylene with alcohol 1a, which was too deactivated for catalysis by ferrocenium hexafluoroantimonate boronic acid. ${ }^{61}$ To our delight, the simple conjugate acid, $\mathrm{HSbF}_{6} \bullet 6 \mathrm{H}_{2} \mathrm{O}$, furnished modest yields of $\mathbf{2 a}$ under otherwise identical conditions (Table 1 , entry 1). Reactivity was improved slightly by using HFIP as the sole solvent (entry 2). $\mathrm{TfOH}$ furnished higher yields due to its superior thermal stability compared to $\mathrm{HSbF}_{6} \bullet 6 \mathrm{H}_{2} \mathrm{O}$ (entry 3). Other strong Lewis and Brønsted acids were also effective (entries 4-5). The addition of catalytic quantities of base to the reaction mixture, or the use of sodium salts or weaker Brønsted acids completely shut down the reaction (entries 6-8). The excess of nucleophile could be reduced to 3 equiv without a large drop in yield (entry 9). Other fluorinated protic solvents were less effective (entries 10-11) and several non-fluorinated common solvents did not produce a detectable amount of $\mathbf{2 a}$ (entries 12-14). 
Table 1. Optimization of conditions ${ }^{\mathrm{a}}$

\begin{tabular}{|c|c|c|c|c|}
\hline & (x equiv) & $\begin{array}{c}\stackrel{\begin{array}{c}\text { catalyst } \\
(10 \mathrm{~mol} \%)\end{array}}{\stackrel{\text { solvent }}{\longrightarrow}} \\
100^{\circ} \mathrm{C}, 24 \mathrm{~h}\end{array}$ & $\mathrm{CF}_{3}$ & Me \\
\hline entry & catalyst & solvent & $x$ & $\begin{array}{l}\text { yield }^{b} \\
(\%)\end{array}$ \\
\hline 1 & $\mathrm{HSbF}_{6} \cdot 6 \mathrm{H}_{2} \mathrm{O}$ & $\mathrm{HFIP} / \mathrm{MeNO}_{2}(4: 1)$ & 5 & 28 \\
\hline 2 & $\mathrm{HSbF}_{6} \cdot 6 \mathrm{H}_{2} \mathrm{O}$ & HFIP & 5 & 39 \\
\hline 3 & $\mathrm{TfOH}$ & HFIP & 5 & 90 \\
\hline 4 & $\mathrm{FeCl}_{3}$ & HFIP & 5 & 18 \\
\hline 5 & $\mathrm{Bi}(\mathrm{OTf})_{3}$ & HFIP & 5 & 90 \\
\hline 6 & $\mathrm{HSbF}_{6} \cdot 6 \mathrm{H}_{2} \mathrm{O}^{\mathrm{c}}$ & HFIP & 5 & $<1$ \\
\hline 7 & $\mathrm{NaSbF}_{6}$ & HFIP & 5 & $<1$ \\
\hline 8 & TFA & HFIP & 5 & $<1$ \\
\hline 9 & $\mathrm{TfOH}$ & HFIP & 3 & 83 \\
\hline 10 & $\mathrm{TfOH}$ & $\mathrm{CF}_{3} \mathrm{CH}_{2} \mathrm{OH}$ & 3 & 19 \\
\hline 11 & $\mathrm{TfOH}$ & $\left(\mathrm{CF}_{3}\right)_{3} \mathrm{COH}$ & 3 & 69 \\
\hline 12 & $\mathrm{TfOH}$ & $\mathrm{MeNO}_{2}$ & 3 & $<1$ \\
\hline 13 & $\mathrm{TfOH}$ & THF & 3 & $<1$ \\
\hline 14 & $\mathrm{TfOH}$ & Toluene & 3 & $<1$ \\
\hline
\end{tabular}

${ }^{a}$ All experiments were conducted in sealed reaction tubes. ${ }^{b}$ Isolated yields of a mixture of regioisomers after silica gel chromatography. See SI for details. ${ }^{c}$ Conducted in the presence of $10 \mathrm{~mol} \%$ Proton Sponge.

A variety of electronically deactivated primary benzylic alcohols and arene nucleophiles were examined to assess the scope of the transformation (Table 2). Benzylic alcohols substituted with single $\mathrm{CN}, \mathrm{NO}_{2}, \mathrm{CF}_{3}$ and $\mathrm{SF}_{5}$ groups reacted efficiently (2b-2e). Impressively, benzylic alcohols bearing up to two $\mathrm{CF}_{3}$ groups, two $\mathrm{NO}_{2}$ groups or up to five fluorines on the aromatic ring were well tolerated $(\mathbf{2} \mathbf{i}-\mathbf{2 k})$. Heteroaromatic nucleophiles were unfortunately not compatible with the reaction conditions. ${ }^{12}$ Pleasingly, less activated nucleophiles such as benzene, fluorobenzene, 1-bromo-2-fluorobenzene and 1,3difluorobenzene are tolerated albeit in lower yield $(2 n-2 p)$.

The success with highly deactivated benzylic alcohols prompted us to explore the possibility that carbenium ions with adjacent electron-withdrawing groups might be generated and trapped directly from the alcohol in a catalytic manner. $\alpha$ Trifluoromethyl cations are synthetically valuable intermediates but difficult to form from the alcohol with catalytic turnover due to a high activation barrier. Consequently, the desired reactivity has previously only been accessed by stepwise or in situ preactivation of alcohols using stoichiometric activating agents or in concentrated $\mathrm{H}_{2} \mathrm{SO}_{4}{ }^{13,14,15}$ Gratifyingly, our standard conditions provide the first example of catalytic access to $\alpha$-trifluoromethyl cations directly from $\alpha$-trifluoromethyl benzylic alcohols, as evidenced by direct dehydrative Friedel-Crafts reactions with a range of nucleophiles (Table 3 ). This reaction provides an efficient catalytic route to non-symmetric fluorinated analogs of the insecticide DDT, complementing existing routes to symmetric analogs. ${ }^{15,16}$ The parent $\alpha$-trifluoromethyl benzylic
Table 2. Scope for deactivated primary benzylic alcohols ${ }^{a}$

$$
\text { (3 equiv) } \underset{\mathrm{HFIP}, 100^{\circ} \mathrm{C}, 24 \mathrm{~h}}{\mathrm{TfOH}(10 \mathrm{~mol} \%)}
$$<smiles>Cc1ccc(Cc2ccc(S(F)(F)(F)(F)F)cc2)c(C)c1</smiles>

2b $(60 \%)^{b, c}$

2c $(91 \%)^{d}$

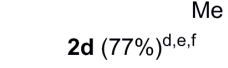<smiles>Cc1ccc(C)c(Cc2c(F)cccc2C(F)(F)F)c1</smiles><smiles>Cc1ccc(C)c(Cc2c(F)cc(F)cc2F)c1</smiles><smiles>Cc1ccc(C)c(Cc2c(F)c(F)cc(F)c2F)c1</smiles>
$2 g(90 \%)$<smiles>Cc1ccc(Cc2ccc(C(F)(F)F)cc2Cc2ccc(C(F)(F)F)cc2C)c(C)c1</smiles>

2h $(81 \%)^{\mathrm{c}, \mathrm{h}}$<smiles>Cc1ccc(C)c(Cc2cc([N+](=O)[O-])cc([N+](=O)[O-])c2)c1</smiles>

2n $(53 \%)^{c, f}$<smiles>Cc1ccc(C)c(Cc2c(F)c(F)c(F)c(F)c2F)c1</smiles><smiles>Fc1c(F)c(F)c(Cc2ccccc2)c(F)c1F</smiles>

$2 \mathrm{~m}(72 \%)$

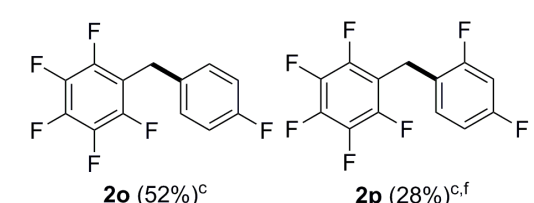

$2 p(28 \%)^{c, f}$

${ }^{\mathrm{a}}$ Isolated yields after column chromatography over silica. ${ }^{\mathrm{b}}$ Performed with 20 $\mathrm{mol} \% \mathrm{TfOH}$. ${ }^{\mathrm{C} C o m b i n e d ~ y i e l d ~ o f ~ r e g i o i s o m e r s . ~ S e e ~ t h e ~ S I ~ f o r ~ m o r e ~ d e t a i l s . ~}$ ${ }^{\mathrm{d}}$ Reaction time was $48 \mathrm{~h}$. ${ }^{\mathrm{e}}$ Performed with $10 \mathrm{~mol}^{\circ} \mathrm{HSbF}_{6} \cdot 6 \mathrm{H}_{2} \mathrm{O}$ as catalyst, $80{ }^{\circ} \mathrm{C}$. ${ }^{\mathrm{f}}$ Performed with 5 equiv of nucleophile. ${ }^{\mathrm{g}}$ Performed at $50{ }^{\circ} \mathrm{C}, 30 \mathrm{~min}$. ${ }^{\mathrm{h}}$ Performed at $50{ }^{\circ} \mathrm{C}, 1 \mathrm{~h}$.

alcohol and aromatic ring furnished the desired diarylmethanes in good to excellent yields (3a-i). Naphthyl-derived alcohols are well tolerated by the reaction system $(\mathbf{3} \mathbf{j}-\mathbf{k})$. Analogs bearing halogens on the aromatic ring provide the product diarylmethanes in more modest synthetic yields (3I-n), but nevertheless offer a handle for further functionalization through metal-catalyzed cross-coupling reactions.

To evaluate whether factors beyond the appealing bulk properties of HFIP solvent might be crucial to expanding the limits of the dehydrative Friedel-Crafts reaction, a solution of pentafluorobenzyl alcohol (1b) in HFIP was titrated with $\mathrm{TfOH}$ and monitored by ${ }^{1} \mathrm{H}$ NMR (Figure 2). In addition to fast proton exchange between $\mathrm{TfOH}$ and the $\mathrm{OH}$ proton of $\mathrm{HFIP}\left(\mathrm{H}_{\mathrm{x}}\right.$ and $\mathrm{H}_{\mathrm{y}}$, respectively), an increasingly downfield shift of the HFIP methine proton $\left(\mathrm{H}_{\mathrm{z}}\right)$ was observed with increasing concentrations of $\mathrm{TfOH}$. In contrast, fast proton exchange was not observed between $\mathrm{TfOH}$ and the $\mathrm{OH}$ proton of $\mathbf{1 b}\left(\mathrm{H}_{n}\right)$, nor was the signal corresponding to the methylene protons of $\mathbf{1 b}\left(\mathrm{H}_{\mathrm{m}}\right)$ observed to shift during the titration, indicating that $\mathrm{TfOH}$ preferentially donates $\mathrm{H}$-bonds to HFIP rather than $\mathbf{1 b}$. Mixed ethers resulting 
Table 3. Scope of diaryltrifluoroethanes ${ }^{a}$<smiles>OC(c1cc[R]cc1)C(F)(F)F</smiles><smiles>Cc1cc(C)c(C(c2ccccc2)C(F)(F)F)c(C)c1</smiles>

3a $(75 \%)^{b}$<smiles>Cc1ccc(C)c(C(c2ccccc2)C(F)(F)F)c1</smiles>

3b $(67 \%)^{b}$

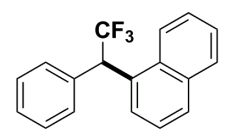

$3 c(85 \%)^{b, d}$<smiles>Cc1ccc(C(c2ccc(C)cc2C)C(c2ccc(C)cc2)C(F)(F)F)cc1</smiles><smiles>COc1ccc(C(c2ccc(OC)cc2)C(c2ccc(OC)cc2)c2cc(C)ccc2C)cc1</smiles>

$3 \mathbf{g}(73 \%)^{c, d}$ 3h $(95 \%)^{\mathrm{c}}$ $3 \mathbf{i}(95 \%)^{c, d}$<smiles>Cc1cc(C)c(C(c2ccc3ccccc3c2)C(F)(F)F)c(C)c1</smiles><smiles>Cc1ccc(C)c(C(c2ccc3ccccc3c2)C(F)(F)F)c1</smiles><smiles>Cc1ccc(C)c(C(c2ccc(Br)cc2)C(F)(F)F)c1</smiles><smiles>Cc1ccc(C)c(C(c2ccccc2F)C(F)(F)F)c1</smiles>

$3 m(13 \%)^{b}$

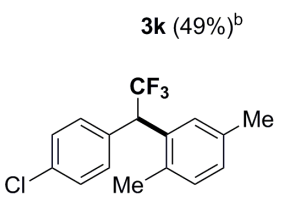

3n $(55 \%)^{b}$

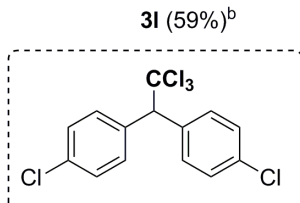

DDT
${ }^{a}$ Isolated yields after column chromatography over silica. ${ }^{b}$ Performed with 20 $\mathrm{mol} \% \mathrm{TfOH}$. ${ }^{\mathrm{c}}$ Performed with $10 \mathrm{~mol} \% \mathrm{TfOH}$. ${ }^{\mathrm{d}}$ Combined yield of regioisomers See the SI for more details. ${ }^{\mathrm{d}}$ Reaction performed at $75^{\circ} \mathrm{C}$.

from dehydrative condensation of HFIP and $\mathbf{1 b}$ were not observed, ruling out the possibility that HFIP ethers serve as a reservoir of benzylic cations. ${ }^{3 a, 10 e}$ However, in the absence of arene nucleophile, ethers resulting from the dehydrative dimerization of $\mathbf{1 b}$ were observed to form in small quantities when higher catalyst loadings ( $>40 \mathrm{~mol} \% \mathrm{TfOH}$ ) were employed. Initial rate kinetics experiments using benzene as nucleophile revealed a first order kinetic concentration dependence on $\mathrm{TfOH}$ and a fifth order concentration dependence on HFIP. ${ }^{17}$ Finally, the reaction of $(-)-1 \mathbf{d}$ with $p$ - xylene under standard conditions led to a near complete loss of stereochemical information in the product, a result consistent

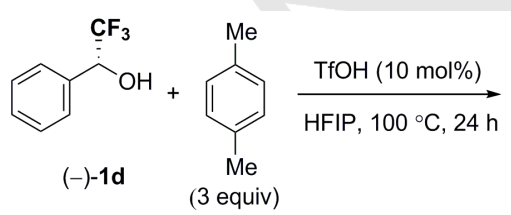

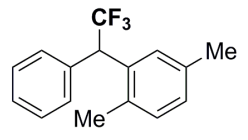

$61 \%$ yield, $4 \%$ ee

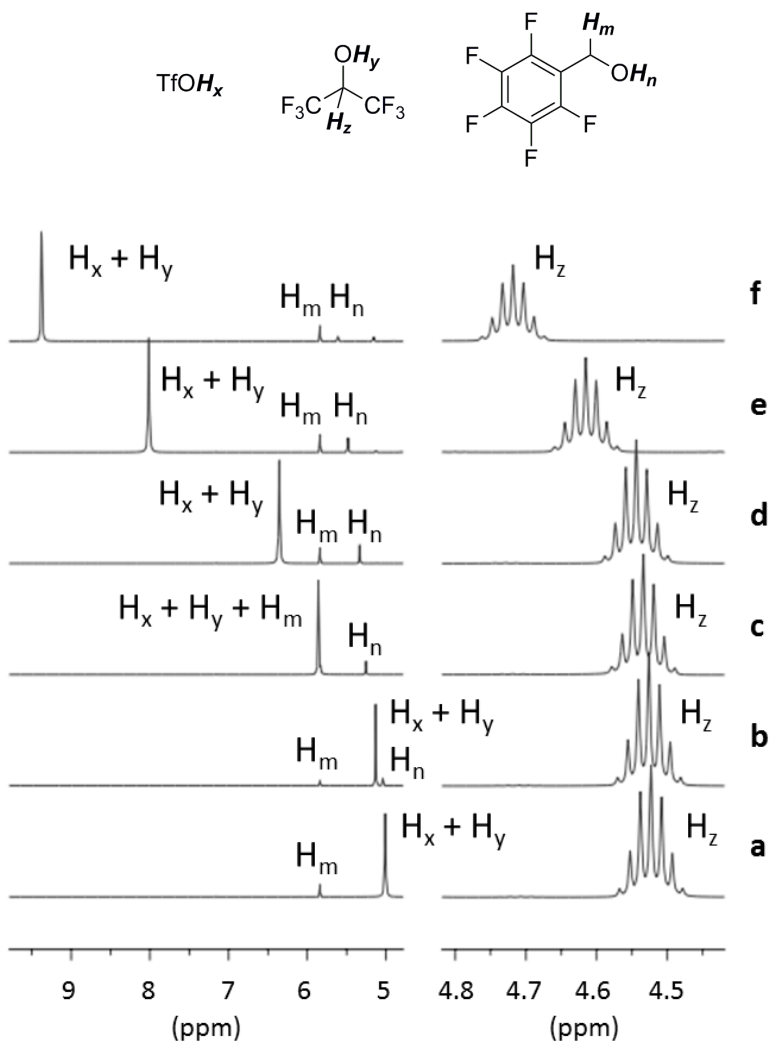

Figure 2. ${ }^{1} \mathrm{H}$ NMR titration of a mixture of HFIP (1 equiv) and $1 \mathbf{b}$ ( 0.050 equiv) with $\mathrm{TfOH}\left(\mathrm{C}_{6} \mathrm{D}_{6}\right.$ as external standard). Spectra were acquired in the presence of the following quantities of $\mathrm{TfOH}$ : a) $0 \mathrm{~mol} \%$; b) $0.5 \mathrm{~mol} \%$; c) $5 \mathrm{~mol} \%$; d) 10 $\mathrm{mol} \%$; e) $43 \mathrm{~mol} \%$; f) $110 \mathrm{~mol} \%$.

with the intermediacy of a carbenium adjacent to the $\mathrm{CF}_{3}$ group (eq 1). Taken together, the titration, initial rate kinetics and racemization experiments and the lack of observation of a "carbenium reservoir" support an $\mathrm{S}_{\mathrm{N}} 1$-type mechanism where HFIP serves to interact with the Brønsted acid to generate higher order mixed aggregates that are superior, and thus the kinetically competent, catalytic species for the ionization of benzylic alcohols. The underappreciated role of HFIP as an $\mathrm{H}-$ bond acceptor ${ }^{18}$ with strong Brønsted acids and the importance of aggregation also lends mechanistic insight into why HFIP appears to be critical in several other Brønsted acid catalysed reactions that have been reported recently. ${ }^{10,19}$

In conclusion, we have described a simple catalytic system that significantly pushes the boundaries of the dehydrative Friedel-Crafts reaction to incorporate highly electronically deactivated benzylic alcohols, including those with a $\mathrm{CF}_{3}$ group adjacent to the $\mathrm{OH}$-bearing carbon. Interactions between the Brønsted acid and HFIP generates catalytically active aggregates in which the $\mathrm{H}$-bond accepting ability of HFIP plays an important role. Further studies are underway to exploit this operationally simple approach to promote a wide variety of Brønsted acid catalyzed transformations that do not otherwise proceed in traditional solvents. 


\section{Acknowledgements}

This project has received funding from the European Research Council (ERC) under the European Union's Horizon 2020 research and innovation programme (grant agreement $n^{\circ}$ 639170). Further funding was provided by grants from LabEx "Chemistry of Complex Systems" and the Marie Curie Actions FP7-PEOPLE Program (CIG-2012-326112). V.D.V. and E.W. thank the French government for MRT fellowships.

\section{Notes}

The authors declare no competing financial interest.

1) C. Friedel, J. M. Crafts, Compt. Rend. 1877, 84, 1450

2) For reviews, see: a) C. C. Price, Org. React. 1946, 3, 1-82; b) R. M. Roberts, A. A. Khalaf, Friedel-Crafts Alkylation Chemistry: A Century of Discovery; Marcel Dekker, Inc.: New York, 1984; c) S. C. Eyley, Comp. Org. Syn. 1991, 2, 707-731; d) M. Rueping, B. J. Nachtsheim, Beilstein J. Org. Chem. 2010, 6, 6.

3) a) G. Shäfer, J. W. Bode, Angew. Chem. Int. Ed. 2011, 50 , 10913-10916; b) J. Zhu, M. Pérez, D. W. Stephan, Angew. Chem. Int $E d$. 2016, 55, 8448-8451; For related methods for non-highly deactivated benzylic fluorides, see: c) P. A. Champagne; Y. Benhassine, J. Desroches, J.-F. Paquin, Angew. Chem. Int. Ed. 2014, 53, 13835-13839; d) R. Hemelaure, P. A. Champagne, J. Desroches, J.F. Paquin, J. Fluor. Chem. 2016, 190, 1-6.

4) D. J. C. Constable, P. J. Dunn, J. D. Hayler, G. R. Humphrey, J. J. L. Leazer, R. J. Linderman, K. Lorenz, J. Manley, B. A. Pearlman, A. Wells, A. Zaks, T. Y. Zhang, Green Chem. 2007, 9, 411-420.

5) For reviews covering the direct dehydrative Friedel-Crafts reactions of alcohols, see: a) M. Bandini, M. Tragni, Org. Biomol Chem. 2009, 7, 1501; b) P. G. Cozzi, F. Benfatti, Angew. Chem. Int. Ed. 2010, 49, 256; c) M. Bandini, Angew. Chem. Int. Ed. 2011, 50, 994; d) E. Emer, R. Sinisi, M. G. Capdevila, D. Petruzziello, F. De Vincentiis, P. G. Cozzi, Eur. J. Org. Chem. 2011, 647; e) B. Sundararaju, M. Achard, C. Bruneau, Chem. Soc. Rev. 2012, 41, 4467; f) R. Kumar, E. V. Van der Eycken, Chem. Soc. Rev. 2013, 42, 1121; g) R. R. Naredla, D. A. Klumpp, Chem. Rev. 2013, 113, 6905; h) A. Baeza, N. Carmen, Synthesis 2014, 46, 25-34; i) L. Chen, X.-P. Yin, C.-H. Wang, J. Zhou, Org. Biomol. Chem. 2014, 12, 6033; j) M. Dryzhakov, E. Richmond, J. Moran, Synthesis 2016, 48, 935-959. See also ref. $2 \mathrm{~d}$.

6) For selected intermolecular examples, see: a) T. Tsuchimoto, $\mathrm{K}$ Tobita, T. Hiyama, S. Fukuzawa, Synlett 1996, 557; b) T. Tsuchimoto, K. Tobita, T. Hiyama, S. Fukuzawa, J. Org. Chem. 1997, 62, 69977005 ; c) K. Mertins, I. Iovel, J. Kischel, A. Zapf, M. Beller, Angew. Chem. Int. Ed. 2005, 44, 238; d) I. Iovel, K. Mertins, J. Kischel, A. Zapf, M. Beller, Angew. Chem. Int. Ed. 2005, 44, 3913; e) J. Choudhury, S. Podder, S. Roy, J. Am. Chem. Soc. 2005, 127, 6162; f) P. G. Cozzi, L. Zoli, Angew. Chem. Int. Ed. 2008, 47, 4162; g) M. Niggemann, M. J. Meel, Angew. Chem. Int. Ed. 2010, 49, 3684; h) E. Wolf, E. Richmond, J. Moran, Chem. Sci. 2015, 6, 2501; i) X. Mo, J. Yakiwchuk, J. Danserau, J. A. McCubbin, D. G. Hall, J. Am. Chem. Soc. 2015, 137, 9694; j) H. Feng, M. Patel, F. Luo, C. Flach, R. Mendelsohn, E. Garfunkel, H. He, M. Szostak, J. Am. Chem. Soc. 2015, 137, 14473-14480.

7) For examples specific to propargylic benzylic alcohols, see: a) Y. Nishibayashi, Y. Inada, M. Yoshikawa, M. Hidai, S. Uemura, Angew. Chem. Int. Ed. 2003, 42, 1495; b) M. Georgy, V. Boucard, J.-
M. Campagne, J. Am. Chem. Soc. 2005, 127, 14180; c) H. Matsuzawa, Y. Miyake, Y. Nishibayashi, Angew. Chem. Int. Ed. 2007, 46, 6488.

8) M. Dryzhakov, M. Hellal, E. Wolf, F. C. Falk, J. Moran, J. Am. Chem. Soc. 2015, 137, 9555 .

9) (a) J.-P. Bégué, D. Bonnet-Delpon, B. Crousse, Synlett 2004, 1, 18-29; b) D. Vuluga, J. Legros, B. Crousse, A. M. Z. Slawin, C. Laurence, P. Nicolet, D. Bonnet-Delpon, J. Org. Chem. 2011, 76, 1126-1133; For the lifetime of dialkylcarbocations in HFIP, see: c) J. P. Pezacki, D. Shukla, J. Lusztyk, J. Warkentin, J. Am. Chem. Soc. 1999, 121, 6589-6598.

10) For examples of HFIP-enabled strong Brønsted acid catalyzed reactions, see: a) A. Saito, M. Takayama, A. Yamazaki, J. Numaguchi, Y. Hanzama, Tetrahedron 2007, 63, 4039-4047; b) H. F. Motiwala, Charaschanya, V. W. Day, J. Aubé, J. Org. Chem. 2016, 81, 15931609; c) X. Zeng, S. Liu, B. Xu, Org. Lett. 2016, 18, 4770-4773; d) W. Liu, H. Wang, C.-J. Li, Org. Lett. 2016, 18, 2184-2187; e) T. Kamitanaka, K. Morimoto, K. Tsuboshima, D. Koseki, H. Takamuro, T. Dohi, Y. Kita, Angew. Chem. Int. Ed. 2016, 55, 15535-15538.

11) For examples of Friedel-Crafts and related reactions that are promoted or assisted by fluorinated alcohol solvents, see: a) M. Hofmann, N. Hampel, T. Kanzian, H. Mayr, Angew. Chem. Int. Ed. 2004, 43, 5402-5404; b) M. Willot, J. Chen, J. Zhu, Synlett 2009, 577580; c) G.-X. Li, J. Qu Chem. Commun. 2010, 46, 2653-2655 ; d) D. Petruzziello, A. Gualandi, S. Grilli, P. G. Cozzi, Eur. J. Org. Chem. 2012, 6697-6701; e) P. Trillo, A. Baeza, C. Najera, J. Org. Chem. 2012, 77, 7344-7354; f) J. Xiao, K. Zhao, T. P. Loh, Chem. Commun. 2012, 48, 3548-3550; g) F.-Z. Zhang, Y. Tian, G.-X. Li, J. Qu, J. Org. Chem. 2015, 80, 1107-1115; h) N. Weisner, M. G. Khaledi, Green. Chem. 2016, 18, 681-685; i) R. H. Vekariya, J. Aubé, Org. Lett. 2016, $18,3534-3537$.

12) Heterocyclic nucleophiles including 2-methylfuran and 2methylthiophene decomposed under the reaction conditions. More surprisingly, the use of methoxybenzene derivatives resulted in no reaction and returned unchanged starting materials.

13) For a review, see: X. Creary, Chem. Rev. 1991, 91, 1625-1678.

14) For generation of $\alpha$-trifluoromethyl cations via tosylates, triflates, bromides and $p$-nitrobenzoates, see: a) A. D. Allen, I. C. Ambridge, C. Che, H. Michael, R. J. Muir, T. T. Tidwell, J. Am. Chem. Soc. 1983, 105, 2343; b) A. D. Allen, R. Girdhir, M. P. Jansen, J. D. Mayo,T. T. Tidwell, J. Org. Chem. 1986, 51, 1324; c) J. P. Richard, J. Am. Chem. Soc. 1986, 108, 6819; d) J. P. Richard, J. Chem. Soc., Chem. Commun. 1987, 1768; e) J. P. Richard, J. Am. Chem. Soc. 1989, 111,1455 ; f) J. P. Richard, Tetrahedron Lett. 1989, 30, 23; g) J. Kwong-Chip; T. T. Tidwell, Tetrahedron Lett. 1989, 30, 1319.

15) E. D. Bergmann, Z. Pelchowicz, A. Shani, Isr. J. Chem. 1963, I, 129.

16) For a route to symmetric fluoroanalogs of DDT from fluorinated hemiacetals, see: G. K. S. Prakash, F. Paknia, T. Matthew, G. Mloston, J. P. Joschek, G. A. Olah, Org. Lett. 2011, 13, 4128.

17) Pentane was employed as an inert co-solvent and the kinetic order in HFIP changed across concentration regimes. See SI for details. For an example of higher order kinetic dependence on HFIP in olefin epoxidation, see: a) A. Berkessel, J. A. Adrio, Adv. Synth. Catal. 2004, 346, 275-280; b) A. Berkessel, J. A. Adrio, D. Hüttenhain, J. M. Neudörfl, J. Am. Chem. Soc. 2006, 128, 8421-8426.

18) For HFIP as H-bond acceptor with the $\mathrm{N}-\mathrm{H}$ bond of piperidine, see: J.-F. Berrien, M. Ourévitch, G. Morgant, N. E. Ghermani, B. Crousse, D. Bonnet-Delpon, J. Fluor. Chem. 2007, 128, 839-843.

19) Previously, only the H-bond donating role of HFIP was discussed with regards to its accelerating effect on Brønsted acid catalyzed reactions (ref. 10d). 
Keywords: Brønsted acid catalysis; alcohols; Friedel-Crafts; carbenium ion; HFIP.

Entry for the Table of Contents: More than a solvent: The use of the fluorinated solvent 1,1,1,3,3,3-hexafluoro-2-propanol (HFIP) and a catalytic amount of a strong Brønsted acid enables dehydrative Friedel-Crafts reactions of highly deactivated benzylic alcohols. Mixed aggregates of acid and HFIP are likely to be involved in the catalysis.

\section{COMMUNICATION}<smiles>OCc1cc(C(F)(F)F)cc(C(F)(F)F)c1</smiles>

Brønsted acid (10 mol\%)

Ar- $-\mathrm{H}$

(3 equiv)

HFIP

$100{ }^{\circ} \mathrm{C}$<smiles>Fc1cc(F)c(Cc2ccc(C(F)(F)F)cc2C(F)(F)F)c(F)c1F</smiles>

Vuk D. Vuković, Edward Richmond, Eléna Wolf, Joseph Moran*

Page No. - Page No.

Catalytic Friedel-Crafts Reactions of Highly Electronically Deactivated Benzylic Alcohols

Cooperativity between Brønsted acid and aggregates of HFIP 